\title{
Penerapan Model Pembelajaran Heuristik Vee untuk Meningkatkan Pemahaman Konsep Matematika Siswa Kelas XI AP4 SMK Negeri 2 Singaraja
}

\author{
N.K.Riantini, I. P.W. Ariawan, Sariyasa \\ Jurusan Matematika Universitas Pendidikan Ganesha \\ Singaraja, Indonesia \\ e-mail: komangrian999@gmail.com, \\ putu wisna ariawan@yahoo.com,sariyasa@undiksha.ac.id
}

\begin{abstract}
Abstrak
Penelitian ini bertujuan untuk: (1) mendeskripsikan proses peningkatan kemampuan pemahaman konsep matematika siswa melalui penerapan model pembelajaran Heuristik Vee dan (2) mengetahui tanggapan siswa terhadap penerapan model pembelajaran Heuristik Vee dalam pembelajaran yang dilaksanakan. Penelitian ini merupakan penelitian tindakan kelas yang dilaksanakan tiga siklus. Subjek penelitian yaitu siswa kelas XI AP4 SMK Negeri 2 Singaraja sebanyak 40 orang. Data kemampuan pemahaman konsep matematika siswa dikumpulkan menggunakan angket. Data yang telah dikumpulkan dianalisis secara deskriptif. Hasil penelitian menunjukkan bahwa persentase banyaknya siswa dengan kemampuan pemahaman konsep matematika yang berada pada kategori tuntas pada siklus I, siklus II, dan siklus III berturut-turut yaitu: $25 \%, 55 \%$, dan $85 \%$. Peningkatan pemahaman konsep matematika siswa tercapai karena beberapa hal yaitu siswa aktif dalam bereksplorasi dan bereksperimen, sehingga siswa mampu menemukan sendiri konsep yang dipelajari dan setiap siswa dibiasakan untuk mampu mempresentasikan hasil diskusi kelompoknya sehingga siswa melakukan diskusi dengan serius. Hal ini berdampak pada peningkatan kemampuan pemahaman konsep matematika siswa. Tanggapan siswa kelas XI AP4 SMK Negeri 2 Singaraja terhadap penerapan model pembelajaran Heuristik Vee berada pada kategori positif. Hal ini dapat dilihat dari rata-rata skor tanggapan siswa yaitu $62,93 \%$
\end{abstract}

Kata kunci: model pembelajaran Heuristik Vee, kemampuan pemahaman konsep matematika

\begin{abstract}
This study aimed to (1) describe the increasing process of the ability to understand the concept of mathematics of the student toward the application of Heuristik Vee learning model in learning. This research was a classroom action research that have beendone in three cycles. The subject that students in grade XI AP4 SMK Negeri 2 Singaraja which there were 40 students. The data of students' ability in understanding mathematics concept were collected by using questionnaire methods. The data that have been gathered then analyzed descriptively. The result of the research shows that the percentage of the number of students who had the ability in understanding mathematics concept which were categorized as complete in cycle I, cycle II, cycle III In a row which are : $25 \%, 55 \%$, and $85 \%$. The increasing of the students' ability in understanding mathematics concept was achieved because of view things whics are the students were active in explorating and experimenting, so the
\end{abstract}


students were able to find the concept of what have been learnt and the stundents were trained to present the discussion result of the group so the students could done is seriously. This affected to the students' ability in understanding mathematics concept. The respone of the students of XI AP4 SMK Negeri 2 Singaraja toward the application of Heuristik Vee learning model was in category positive. This can be seen from the students' average score which was $62,93 \%$.

Key words: Heuristik Vee learning model, the ability in understanding mathematics concept.

\section{PENDAHULUAN}

IImu pengetahuan dan teknologi (IPTEK) telah berkembang sangat pesat dan telah merevolusi cara hidup manusia, baik cara berkomunikasi, cara belajar, cara bekerja, cara berbisnis, dan lain sebagainya. Untuk menghadapi tantangan IPTEK tersebut, dituntut sumber daya manusia yang handal dan mampu bersaing secara global. Oleh karena itu, diperlukan manusia yang berkualitas dan mempunyai keterampilan tinggi, sistematis, logis dan kreatif.

Mengembangkan dan menyiapkan sumber daya manusia yang berkualitas serta memiliki kesiapan untuk menghadapi kemajuan ilmu pengetahuan dan teknologi tidak lepas dari peranan pendidikan. Pendidikan adalah suatu hal yang penting dalam tatanan kehidupan manusia. Pendidikan bermula disaat manusia terlahir dan berlangsung seumur hidup dengan tujuan agar menjadi manusia berkembang yang berguna bagi masyarakat, bangsa, dan negara.

Perkembangan IPTEK yang begitu pesat tak terlepas dari dukungan matematika. Matematika sangatlah penting dan bukan sekedar aplikasi keterampilan dasar berhitung. Matematika merupakan sarana utama untuk mengembangkan pikiran logis pada anak-anak dan merupakan keterampilan kognitif tingkat tinggi. Matematika juga memainkan peran utama pada disiplin ilmu lain, seperti fisika, statistik dan teknik sehingga dapat disimpulkan bahwa salah satu upaya untuk menguasai IPTEK ialah dengan menguasai matematika. Penguasaan matematika yang baik tentu didukung dengan pembelajaran matematika yang baik pula.
Keberhasilan pembelajaran matematika dapat diukur dari keberhasilan siswa yang mengikuti kegiatan pembelajaran tersebut. Keberhasilan itu dapat dilihat dari tingkat pemahaman, penguasaan materi, dan prestasi belajar siswa. Semakin tinggi pemahaman, penguasaan materi, semakin tinggi pula prestasi belajar siswa.

Pembelajaran matematika adalah salah satu pembelajaran yang penting untuk diperhatikan. Hal ini karena pembelajaran matematika berlangsung di semua jenjang pendidikan, mulai dari jenjang pendidikan dasar, pendidikan menengah, dan pendidikan tinggi. Dibelajarkannya matematika pada setiap jenjang pendidikan tidak terlepas dari hakikat matematika sebagai sumber dari ilmu pengetahuan lainnya yang menggunakan konsep matematika dan juga merupakan ilmu yang penerapannya banyak dibutuhkan dalam kehidupan sehari-hari serta sangat berperan penting dalam meningkatkan kualitas pendidikan, sehingga diperlukan penguasaan matematika yang kuat sejak dini (Suherman, dkk, 2003). Berkaitan dengan pentingnya peranan matematika dalam kehidupan dan pengembangan pengetahuan, sudah sepantasnya konsepkonsep matematika perlu dikuasai dengan baik oleh siswa. Hal ini sesuai dengan salah satu tujuan pembelajaran matematika menurut Depdiknas (2006) yaitu memahami konsep matematika, menjelaskan keterkaitan antar konsep dan mengaplikasikan konsep atau algoritma secara luas, akurat, efisien dan tepat dalam pemecahan masalah.

Kenyataannya belum semua kemampuan tersebut dikuasai dengan baik 
oleh siswa. Banyak permasalahan yang menjadi faktor penyebab kemampuankemampuan tersebut belum dikuasai dengan baik oleh siswa. Beberapa permasalahan dalam pembelajaran matematika juga dirasakan terjadi di kelas XI AP 4 SMK Negeri 2 Singaraja. Untuk mengidentifikasi masalah yang terjadi di kelas tersebut, dilakukanlah berbagai upaya pengumpulan informasi baik melalui kegiatan observasi dan wawancara. Berdasarkan hasil observasi kelas dan wawancara bersama dengan guru serta siswa kelas XI AP4 SMK Negeri 2 Singaraja. Berdasarkan pengamatan langsung yang dilakukan di dalam kelas pada awal proses pembelajaran, guru memberikan apersepsi dengan memberikan permasalahan seputar oprasi matriks, seperti syarat dua buah matriks $A$ dan $B$ dapat dijumlahkan, dikurangkan dan dikalikan. Dalam tanya jawab tersebut masih terlihat siswa yang kebingungan dan salah konsep dalam menyelesaikan oprasi matriks serta masih kesulitan menyebutkan ordo suatu matriks bahkan masih ada juga yang sering keliru menyebutkan mana yang termasuk baris dan mana yang termasuk kolom dalam matriks. Dari hasil wawancara dan observasi tersebut peneliti dengan dibantu oleh guru mengidentifikasi bahwa siswa kelas XI AP4 SMK Negeri 2 Singaraja mangalami masalah terhadap pemahaman konsep siswa.

Selain wawancara dengan guru serta observasi proses pembelajaran di kelas, beberapa faktor yang diduga menyebabkan rendahnya pemahaman konsep siswa adalah sebagai berikut.

1. Pembelajaran matematika yang diterapkan masih belum dapat sepenuhnya menarik perhatian siswa untuk belajar secara optimal. Ketika pembelajaran berlangsung nampak bahwa siswa kurang memperhatikan dengan baik penjelasan guru ataupun temannya yang mengajukan pertanyaan ataupun menyampaikan pendapat.

2. Siswa jarang menunjukkan potensi yang dimiliki, kurang berinteraksi baik antara siswa dengan siswa maupun siswa dengan guru. Penyebabnya adalah siswa tidak pernah dihadapkan dengan siswa lain secara kompetitif untuk menyampaikan idenya dan membuat siswa merasa tertantang untuk menyampaikan idenya.

3. Siswa belum mampu memahami konsep yang diajarkan dengan baik, sehingga penguasaan konsep yang dimiliki siswa hanya bersifat jangka pendek. Hal yang ditemukan pada saat observasi yaitu apabila diberikan permasalahan baru, siswa belum dapat mengaitkan dan menggunakan konsep sebelumnya yang telah dipelajari.

Untuk mendapatkan informasi lebih lanjut mengenai pemahaman konsep matematika siswa, peneliti dibantu oleh guru yang mengajar dikelas memberikan tes sebagai analisis pemahaman konsep matematika terhadap materi ajar yang sudah diajarkan kepada 40 siswa kelas XI AP4 SMK Negeri 2 Singaraja. Berdasarkan rekapitulasi nilai tes pemahaman konsep yang dilakukan kepada 40 siswa yang terdiri dari 25 siswa laki-laki dan 15 siswa perempuan, masih banyak dibawah kriteria ketuntasan minimal (KKM) yaitu 70

Melalui wawancara,observasi dan hasil tes tersebut dalam kegiatan pembelajaran yang dilakukan di kelas, penulis berkolaborasi dengan guru di kelas mengkaji permasalahan yang dialami siswa, bahwa siswa belum mampu memahami konsep yang diajarkan dengan baik, sehingga penguasaan konsep yang dimiliki siswa hanya bersifat jangka pendek, dan juga pembelajaran yang dilakukan tidak membantu siswa dalam mengkonstruksi pemahaman konsep siswa. Hal ini menyebabkan pembelajaran menjadi kurang bermakna dan kurang memberikan kesempatan kepada siswa untuk belajar aktif. Oleh karena itu, diperlukan suatu upaya untuk meningkatkan pemahaman konsep matematika siswa kelas XI AP4 SMK Negeri 2 Singaraja. Melalui penelitian tindakan kelas ini akan dicoba suatu pembelajaran dengan setting pembelajaran Heuristik Vee dimana pembelajarannya dapat mengkonstruksi 
pengetahuan dan pemahaman konsep siswa.

Model pembelajaran Heuristik Vee merupakan cara pemecahan masalah dengan menggunakan prosedur-prosedur penemuan (discovery) dalam matematika. Dinamakan Heuristik Vee karena mengambil bentuk huruf " $\mathrm{V}$ ". bentuk ini berfungsi untuk memberikan penekanan dasar-dasar pengetahuan penting yang terlibat dalam kontruksi pengetahuan baru atau arti baru. Jadi Heuristik Vee dapat diartikan sebagai cara memecahkan masalah dengan menggunakan prosedurprosedur penemuan yang dituangkan dalam diagram " $\mathrm{V}$ ".

Diagram Vee terdiri dari dua bagian yaitu bagian kiri yang disebut dengan sisi konseptual atau teoritis dan bagian kanan merupakan sisi metodologi/proses. Pada sisi konseptual (sebelah kiri "V") berisi teoriteori, prinsip-prinsip, dan konsep-konsep. Gagasan atau sejenis "teori siswa" mengenai peristiwa-peristiwa perlu dibuktikan kebenarannya dengan mengamati suatu objek atau peristiwaperistiwa (bagian bawah "V") melalui suatu percobaan. Pada sisi metodologis (sisi kanan "V") berisi catatan-catatan yang harus dibuat, tranformasi, serta klaim pengetahuan (generalisasi dan nilai). Pembuatan catatan perlu mempertimbangkan konsep dan catatan yang dibuat sesuai. Pada bagian atas "V" diletakkan pertanyaan kunci yang berfungsi untuk menuntun siswa dalam melakukan penyelidikan (Suastra, 2009).

Model pembelajaran Heuristik Vee memiliki lima tahapan dalam penerapannya, yaitu (1) Tahap 1 orientasi. siswa. Tahap ini guru memusatkan perhatian peserta didik dengan menyebutkan beberapa fenomena dalam kehidupan sehari-hari yang berkaitan dengan topik yang akan dipelajari. (2) Tahap 2 pengungkapan Gagasan Peserta didik. Tahap ini Guru meminta peserta didik untuk mengungkapkan gagasan konseptual yang dimilikinya dengan memberikan pertanyaan-pertanyaan yang ada kaitanya dengan kehidupan seharihari.(3) Tahap 3 Pengungkapan permasalahan/ fokus pertanyaan. Tahap ini Guru mengajukan permasalahan yang berkaitan dengan penyelidikan yang dilakukan dalam bentuk pertanyaan kunci. (4)Tahap4 pengkonstruksian pengetahuan baru. Untuk mengkonstruksi pengetahuan baru peserta didik diminta melakukan eksperimen. Guru mengawasi siswa dan memberikan bimbingan seperlunya. Guru meminta peserta didik untuk memberikan komentar terhadap hasil pengamatan serta menuangkannya dalam diagram Vee. (5) Tahap 5 evaluasi, tahapan ini bertujuan mengevaluasi gagasan mana yang paling benar untuk menjelaskan fenomena yang dipelajari dan pengkonstruksian pengetahuan yang baru, peserta didik diminta melakukan tanya jawab (diskusi) yang dipandu oleh guru. Guru mencatat ide-ide pokok yang sesuai dengan konsep dan mendiskusikan jawaban peserta didik yang salah. Dengan demikian peserta didik dapat melihat ketidak sesuaian gagasan yang dimiliki sebelumnya dan kemudian merekontruksi. Model pembelajaran heuristik Vee memberikan kesempatan kepada siswa untuk mengontruksikan pengetahuannya sendiri melalui aktifitas yang konkrit dan relevan dengan materi pelajaran. Siswa dapat mengungkapkan gagasan awal yang mereka miliki, mencari tahu konsep yang dipelajari melalui pengamatan, dan demontrasi yang disesuaikan dengan materi pelajaran. Selain itu siswa juga diberikan kesempatan untuk berdiskusi dan bertukar pikiran dengan temannya. Hal ini akan mengakibatkan kemampuan siswa dalam menguasai konsep-konsep akan semakin bagus dan meningkat. Maka dari itu dengan model pembelajaran Heuristik Vee ini diharapkan mampu menanamkan kesadaran pada diri siswa untuk meningkatkan dan memantapkan pemahaman konsep matematika siswa.

$$
\text { Berdasarkan pemaparan }
$$

sebelumnya tindakan yang sangat tepat untuk mengatasi masalah yang terjadi di kelas XI AP4 SMK Negeri 2 Singaraja dengan model pembelajaran Heuristik Vee dan didukung oleh pembelajaran yang berpusat pada siswa diharapkan mampu 
memantapkan pemahaman konsep matematika siswa terutama dalam mengaplikasikan konsep tersebut. Oleh karena itu penulis tertarik untuk menerapkan model pembelajaran Heuristik Vee ini dalam pembelajaran matematika melalui penelitian dengan judul "Penerapan Model Pembelajaran Heuristik Vee untuk Meningkatkan Pemahaman Konsep Matematika Siswa Kelas XI AP4 SMK Negeri 2 Singaraja".

\section{METODE}

Penelitian ini merupakan penelitian tindakan Kelas (Classroom Action Research) yang bersifat kolaboratif, yang secara umum bertujuan untuk meningkatkan dan memperbaiki kualitas pembelajaran di Kelas XI AP4 di SMK Negeri 2 Singaraja yang bermuara pada meningkatnya pemahaman konsep matematika siswa. Tahapan yang dilakukan dalam penelitian tindakan kelas ini yaitu 1) Perencanaan, 2) Pelaksanaan, 3) Pengamatan, dan 4) Refleksi. Keterlibatan peneliti dalam pembelajaran dalam bentuk kolaborasi antara peneliti dan guru matematika di SMK Negeri 2 Singaraja sehingga memungkinkan terjadinya pemahaman dan kesepakatan terhadap suatu masalah yang dihadapi, pengambilan keputusan yang demokratis sehingga melahirkan kesamaan persepsi terhadap tindakan yang dilakukan.

Subjek dalam penelitian ini adalah semua siswa Kelas XI AP4 SMK Negeri 2 Singaraja semester genap tahun pelajaran 2017/2018 sebanyak 40 siswa yang terdiri dari 25 siswa laki-laki dan 15 siswa perempuan yang keseluruhan siswa lakilaki. Sedangkan, objek dalam penelitian ini adalah (1) pemahaman konsep matematika siswa XI AP 4 SMK Negeri 2 Singaraja, (2) tanggapan siswa terhadap penerapan model pembelajaran Heuristik Vee dalam pembelajaran Matematika.

Instrumen dalam penelitian ini berupa angket dan tes, angket digunakan untuk mengumpulkan data mengenai tanggapan siswa terhadap penerapan model pembelajaran Heuristik Vee dalam pembelajaran Matematika. Sedangkan Tes yang digunakan untuk mengumpulkan data pemahaman konsep matematika siswa berbentuk soal uraian. Selain itu peneliti juga menggunakan lembar observasi sebagai tambahan untuk menilai sikap dalam proses pembelajaran.

Data yang terkumpul selanjutnya dianalisis secara deskriptif, yaitu skor pemahaman konsep matematika siswa yang ditinjau dari Kriteria Ketuntasan Minimal (KKM) Mata Pelajaran Matematika dan ketuntasan belajar siswa secara klasikal serta rata-rata skor tanggapan siswa untuk data tanggapan siswa. Kriteria yang digunakan dalam penggolongan pemahaman konsep matematika siswa disajikan pada Tabel 1.

Tabel 1. Kriteria Ketuntasan Pemahaman Konsep Matematika

\begin{tabular}{cc}
$\begin{array}{c}\text { Pemahaman Konsep } \\
\text { Matematika }\end{array}$ & Kategori \\
\hline $\mathbf{7 0} \leq \overline{\boldsymbol{X}} \leq \mathbf{1 0 0}$ & Tuntas \\
$\mathbf{0} \leq \overline{\boldsymbol{X}}<\mathbf{7 0}$ & Belum Tuntas \\
\hline
\end{tabular}

Ketuntasan belajar siswa (KB) secara klasikal dihitung dengan menggunakan rumus sebagai berikut.

$$
K B=\frac{N}{n} \times 100 \%
$$

dengan $K B=$ ketuntasan belajar, $N=$ banyak siswa yang tuntas, $n=$ banyak siswa.

Selanjutnya data tanggapan siswa dianalisis secara deskriptif berdasarkan rata-rata skor $(\bar{R})$, mean ideal $(M I)$, dan standar deviasi ideal $(S D I)$, ditentukan dengan kriteria berikut:

Tabel 2. Kriteria Penggolongan Skor tanggapan Siswa

\begin{tabular}{cc}
\hline Rentang Skor & Kategori \\
\hline $\bar{R} \geq 63$ & Sangat Positif \\
$51 \leq \bar{R}<63$ & Positif \\
$39 \leq \bar{R}<51$ & Cukup \\
$27 \leq \bar{R}<39$ & Negatif \\
$\bar{R}<27$ & Sangat Negatif \\
\hline
\end{tabular}

\section{HASIL DAN PEMBAHASAN}

Sebagaimana yang telah
dipaparkan pada bab
sebelumnya,penelitian tindakan kelas ini
dilaksanakan pada semester genap tahun 
ajaran 2017/2018 di kelas XI AP4 SMK Negeri 2 Singaraja, dengan subjek penelitian sebanyak 40 orang. Secara umum pelaksanaan pembelajaran matematika selama penelitian ini berlangsung sesuai dengan rencana pelaksanaan pembelajaran yang telah disusun. Penelitian ini dilaksanakan dalam tiga siklus untuk pkok pembahasan Transformasi Geometri. Setiap siklus dilaksanakan dalam empat kali pertemuan yaitu tiga kali pertemuan dan untuk pembelajaran dan satu kali pertemuan untuk pelaksanaan tes pemahaman konsep matematika siswa.

Data yang dikumpulkan dalam penelitian ini meliputi dua pemahaman konsep matematika siswa dan data tanggapan siswa terhadap penerapan model pembelajaran Heuristik Vee dalam pembelajaran yang diterapkan. Data tersebut dikumpulkan sesuai dengan teknik pengumpulan data dan dianalisis sesuai dengan teknik analisis data yang telah dijelaskan pada bab sebelumnya. Adapun hasil dari analisis data mengenai pemahaman konsep matematika siswa dan analisis data tanggapan siswa mengenai pembelajaran yang diterapkan secara terperinci akan dipaparkan sebagai berikut.

Data pemahaman konsep matematika siswa pada siklus I disajika pada Lampiran 07. Dar hasil analisis data pemahaman konsep matematikia siswa pada siklus I terlihat bahwa nilai terendah adalah 27,02 dan nilai tertinggi adalah 86,48 . Persentase banyaknya siswa yang nilai pemahaman konsepnya belum tuntas adalah $75 \%$ (30 orang), sedangkan persentase banyaknya siswa yang nilai pemahaman konsepnya sudah tuntas adalah 25\% (10 orang). Dengan demikian, ketuntasan belajar siswa secara klasikal dapat dihitung sebagai berikut.

$K B=\frac{N}{n} \times 100 \%=\frac{10}{40} \times 100 \%=25 \%$

Ketuntasan belajar siswa dalam memahami konsep matematika pada siklus I, disajikan pada Gambar 1 berikut.

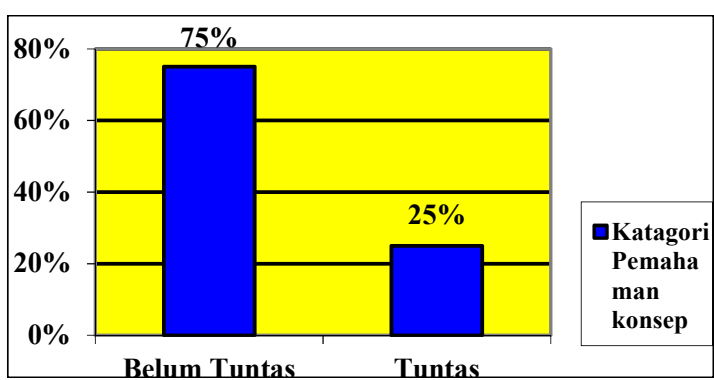

Gambar 1Grafik Ketuntasan Belajar Siswa Secara Klasikal Pada Siklus I

Berdasarkan analisis data di atas, dapat disimpulkan bahwa ketuntasan belajar matematika siswa kelas XI AP4 SMK Negeri 2 Singaraja pada siklus I belum memenuhi indikator keberhasilan yang telah ditetapkan, karena ketuntasan belajar siswa secara klasikal belum mencapai $75 \%$. Tetapi, ketuntasan belajar siswa secara klasikal sudah mengalami peningkatan dari refleksi awal ke siklus.

Dari hasil evaluasi selama pelaksanaan pembelajaran pada siklus I teridentifikasi beberapa permasalahan yang menyebabkan kurang optimalnya proses pembelajaran pada siklus I, yaitu sebagai berikut.

1. Siswa belum terbiasa dengan model pembelajaran yang diterapkan karena pada model ini siswa yang harus aktif dalam menemukan berbagai informasi dari buku paket sebagai sumber yang ada dan pengajar hanya sebagai pemantau dan fasilitator.

2. Masih terdapat siswa yang malu dalam menyampaikan pemikirannya kepada pasangan dalam kelompok diskusi. Saat melaksanakan diskusi kelompok, siswa yang mempunyai kemampuan akademik kurang, cenderung ragu untuk mengungkapkan pendapat atau malu bertanya dengan teman kelompoknya. Sebaliknya, siswa yang memiliki kemampuan akademik baik (guru siswa), belum dapat memberikan penjelasan kepada teman kelompoknya yang belum mengerti

3. Masih terdapat siswa yang mengalami kesulitan dalam mengerjakan Lembar Kerja Siswa. Siswa belum fokus dengan pembelajaran yang diberikan.kemudian masih kebingungan dalam mengerjakan 
pertanyaan-pertanyaan dalam diagram Vee dan cenderung masing perlu dibimbing atau berikan petunjuk dalam mengerjakannya karena LKS yang digunakan masih tergolong baru bagi mereka.

4. Saat salah satu perwakilan kelompok menjelaskan hasil diskusinya di depan kelas masih terdapat siswa yng tidak memperhatikan penjelasan dari siswa tersebut.

5. Dalam menjawab soal kuis, masih terdapat siswa yang kekurangan waktu untuk menjawab soal dengan cepat dan tepat. Siswa yang bersangkutan masih meminta waktu tambahan untuk menyelesaikan soal yang diberikan. Selain itu, siswa gugup dalam melakukan presentasi dan menjelaskan jawabannya di depan kelas. Siswa terlihat malu dan kurang percaya diri dengan jawaban yang diperoleh.

6. Terdapat siswa yang belum berani untuk bertanya dan menyampaikan pendapat pada saat pembelajaran berlangsung. Seperti saat guru menyatakan bahwa jawaban siswa benar, siswa lain terlihat malu untuk bertanya terkait dengan hal-hal yang belum dipahami. Sehingga untuk selanjutnya, siswa kembali mengalami kesulitan untuk menyelesaikan soalsoal yang diberikan guru.

Dalam pemahaman konsep matematika pada siklus II disajika pada Lampiran 11. Dari hasil analisis data pemahman konsep matematika siswa pada siklus II terlihat bahwa nilai terendah adalah 35 dan nilai tertinggi 90 . Persentase banyaknya siswa nilai pemahaman konsepnya belum tuntas adalah 45\% (18 orang), sedangkan persentase banyaknya siswa yang nilai pemahaman konsepnya sudah tuntas adalah 55\% (22 orang). Dengan demikian, ketuntasan belajar siswa secara klasikal, dapat dihitung sebagai berikut.

$$
K B=\frac{N}{n} \times 100 \%=\frac{22}{40} \times 100 \%=55 \%
$$

Ketuntasan belajar siswa dalam memahami konsep matematika pada siklus II, disajikan pada Gambar 2 berikut.

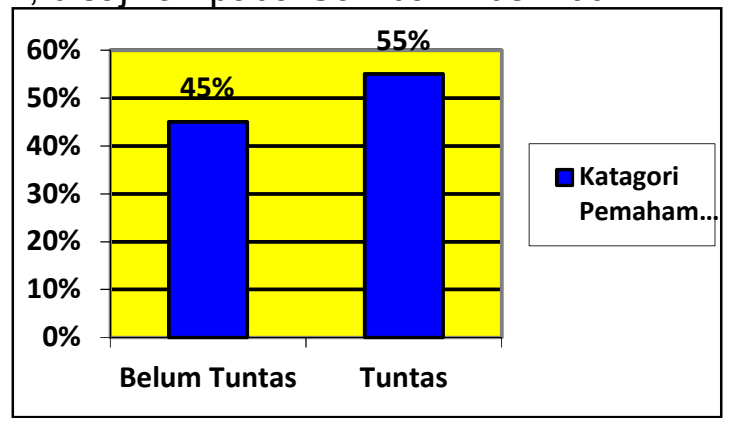

Gambar 2Grafik Ketuntasan Belajar Siswa Secara Klasikal Pada Siklus II

Berdasarkan analisis data di atas, dapat disimpulkan bahwa ketuntasan belajar matematika siswa XI AP4 SMK Negeri 2 Singaraja pada siklus II belum memenuhi indikator keberhasilan yang telah ditetapkan, karena ketuntasan belajar siswa secara klasikal belum mencapai $75 \%$. Tetapi, ketuntasan belajar siswa secara klasikal sudah mengalami peningkatan dari siklus I ke siklus II

Walaupun hasil pada siklus II lebih baik daripada siklus I, berdasarkan hasil refleksi yang dilakukan pada siklus II, penelitian bersama guru kembali mengkaji permasalahan-permasalahan terkait dengan pelaksanaan tindakan yang telah dilakukan serta upaya perbaikannya sebagai pedoman untuk pelaksanaan tindakan pada siklus III. Adapun permasalahan-permasalahan yang ditemukan selama pelaksanaan siklus II adalah sebagai berikut.

1. Beberapa kelompok siudah mampu membuat kesimpulan terkait materi yang sedang dipelajar, namun ada beberapa kelompok yang masih membutuhkan bimbingan guru dalam membuat kesimpulan.

2. Pada saat pembelajaran berlangsung, masih ada beberapa siswa yang kurang aktif. Mereka hanya mengandalkan anggota kelompok yang dirasa lebih pintar dari dirinya dalam mengerjakan permasalahan yang ada pada LKS.

3. Pada saat mengerjakan LKS, masih ada beberapa siswa yang masih 
kebingungan dalam mengerjakan LKS pada bagian pengisian diagram Vee.

4. Dalam mempersentasikan hasil diskusi, beberapa kelompok terlihat hanya mengandalkan orang sama, anggota kelompok yang lain merasa takut salah dalam menyampaikan hasil diskusi kelompoknya.

5. Pada saat mengerjakan soal cerita yang berkaitan dengan materi yang sedang dipelajari siswa mengalami kebingungan terkait maksud dari soal tersebut.

Data pemahaman konsep matematika siswa pada siklus III disajikan pada Lampiran 15. Dari hasil analisis data pemahaman konsep matematika siswa pada siklus III terlihat bahwa nilai terendah adalah 50 dan nilai tertinggi 96. Persentase banyaknya siswa yang nilai pemahaman konsepnya belum tuntas adalah 15\% (6 orang), sedangkan persentase banyak siswa yang nilai pemahaman konsepnmya sudah tuntas adalah $85 \%$ (34 orang). Dengan demikian, ketuntasan belajar siswa secara klasikal, dapat dihitung sebagai berikut.

$K B=\frac{N}{n} \times 100 \%=\frac{34}{40} \times 100 \%=85 \%$

Ketuntasan belajar siswa dalam memahami konsep matematika pada siklus III, disajikan pada Gambar 3 berikut.

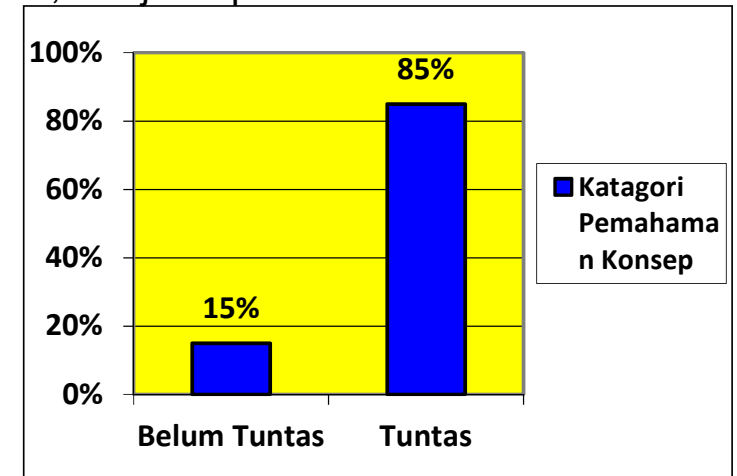

Gambar 3 Grafik Ketuntasan Belajar Siswa Secara Klasikal Pada Siklus III

Berdasarkan analisis data pada siklus III, dapat disimpulkan bahwa ketuntasan belajar matematika siswa kelas XI AP4 SMK Negeri 2 Singaraja pada siklus III sudah memenuhi indikator keberhasilan yang telah ditetapkan, karena ketuntasan belajar siswa mengalami peningkatan dari siklus II ke siklus III.

Berdasarkan hasil refleksi siklus III terlihat bahwa pembelajaran pada siklus III, baik dari segi hasil maupun proses pembelajaran menunjukkan peningkatan yang optimal dari siklus sebelumnya. Adapun temuan-temuan selama pelaksanaan tindakan siklus III adalah sebagai berikut.

1. Secara umum proses pembelajaran telah berjalan sesuai dengan rencana pelaksanaan pembelajaran (RPP) yang telah direncanakan. Guru dan siswa sudah terbiasa dengan kegiatan pembelajaran yang diterapkan. Hal ini terlihat dari semakin efektifnya penggunaan alokasi waktu yang telah direncanakan. Setiap tahapan yang ada pada model pembelajaran Heuristik Vee dapat dilalui dengan baik oleh siswa maupun guru.

2. Kondisi pembelajaran semakin kondusif dan siswa terlihat antusias dalam mengikuti pembelajaran. Hal ini terlihat dari banyaknya siswa yang mau dan berani dalam memberikan tanggapan, jawaban, maupun pertanyaan serta dalam berinteraksi dengan guru dan siswa lain selama proses pembelajaran berlangsung.

3. Dalam pelaksanaa diskusi kelompok, tidak lagi hanya didominasikan oleh siswa yang pintar saja, namun setiap siswa sudah mau berdiskusi dengan anggota kelompoknya dan merasa memiliki tanggung jawab yang sama dalam menyelesaikan permasalahan yang diberikan. Hal ini berdampak positif pada proses pembelajaran yang dilaksanakan.

4. Sebagian besar kelompok sudah mampu mengerjakan soal atau permasalahan yang diberikan dengan lengkap dan baik, meskipun terkadang masih ada beberpa kesalahan, seperti kesalahan perhitungan ataupun kesalahan dalam mengisi satuan/

5. Sudah banyak siswa yang mampu memahami konsep dengan baik dan benar. Hal ini terlihat dari sebagian besar siswa sudah mampu 
menyatakan konsep dengan kata-kata sendiri, memberikan atau membedakan contoh dan bukan contoh dari suatu konsep serta mengaplikasinan konsep tersebut untuk menyelesaikan juga ditunjukkan dari hasil tes pemahaman konsep matematika siswa pada siklus III yang sudah memenuhi indikator keberhasilan dan merupakan peningkatan yang paling optimal Dario siklus-siklus sebelumnya.

Ringkasan data pemahaman konsep matematika siswa pada tahap refleksi awal, siklus I, siklus II, dan siklus III dapat dilihat pada Tabel 3 berikut.

Tabel 3 Ringkasan Data Pemahaman Konsep Matematika

\begin{tabular}{|c|c|c|c|c|c|c|c|c|c|}
\hline \multirow{2}{*}{$\begin{array}{l}\mathbf{N} \\
\mathbf{0}\end{array}$} & \multirow{2}{*}{$\begin{array}{l}\text { Kata } \\
\text { gori }\end{array}$} & \multicolumn{2}{|c|}{$\begin{array}{l}\text { R.Awa } \\
\text { I }\end{array}$} & \multicolumn{2}{|c|}{$\begin{array}{l}\text { Siklu } \\
\text { s I }\end{array}$} & \multicolumn{2}{|c|}{$\begin{array}{l}\text { Siklu } \\
\text { s II }\end{array}$} & \multicolumn{2}{|c|}{$\begin{array}{l}\text { Siklu } \\
\text { s III }\end{array}$} \\
\hline & & $\mathbf{F}$ & $\mathbf{P}$ & $F$ & $\mathbf{P}$ & $F$ & $\mathbf{P}$ & $F$ & $\mathbf{P}$ \\
\hline 1 & $\begin{array}{l}\text { Belu } \\
\mathrm{m} \\
\text { Tunt } \\
\text { as }\end{array}$ & $\begin{array}{l}4 \\
0\end{array}$ & $\begin{array}{l}10 \\
0 \\
\%\end{array}$ & $\begin{array}{l}3 \\
0\end{array}$ & $\begin{array}{l}7 \\
5 \\
\%\end{array}$ & $\begin{array}{l}1 \\
8\end{array}$ & $\begin{array}{l}4 \\
5 \\
\%\end{array}$ & 6 & $\begin{array}{l}1 \\
5 \\
\%\end{array}$ \\
\hline 2 & Tuntas & 0 & $\begin{array}{l}0 \\
\%\end{array}$ & $\begin{array}{l}1 \\
0\end{array}$ & $\begin{array}{l}2 \\
5 \\
\% \\
\end{array}$ & $\begin{array}{l}2 \\
2\end{array}$ & $\begin{array}{l}5 \\
5 \\
\% \\
\end{array}$ & $\begin{array}{l}3 \\
4\end{array}$ & $\begin{array}{l}8 \\
5 \\
\% \\
\end{array}$ \\
\hline \multicolumn{2}{|c|}{$\begin{array}{l}\text { Ketuntasa } \\
\text { Belajar } \\
\text { Klasikal }\end{array}$} & \multicolumn{2}{|c|}{$0 \%$} & \multicolumn{2}{|c|}{$25 \%$} & \multicolumn{2}{|c|}{$55 \%$} & \multicolumn{2}{|c|}{$85 \%$} \\
\hline
\end{tabular}

Keterangan : $\mathrm{F}=$ Frekuensi

\section{$\mathrm{P}=$ Persentase}

Berdasarkan tabel 3 terlihat bahwa pemahaman konsep matematika siswa kelas XI AP4 SMK Negeri 2 Singaraja mengalami peningkatan dari reflesksi awal sampai siklus III. Peningkatan ketuntasan belajar siswa pada refleksi awal siklus I, siklus II, dan siklus III disajikan pada Gambar 4 berikut.

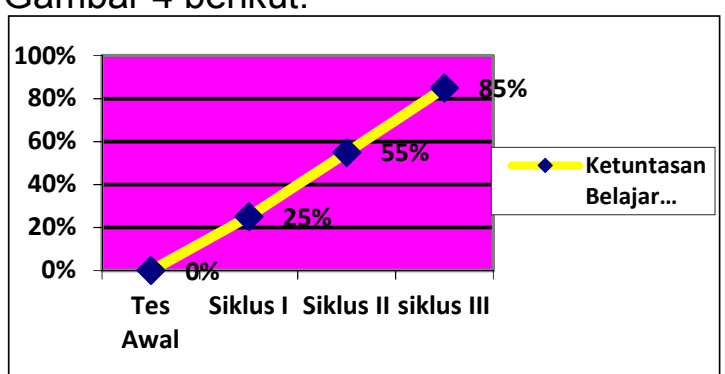

Gambar 4 Grafik Peningkatan Ketuntasan Belajar Secara Klasikal

Data mengenai tanggapan siswa terhadap penerapan model pembelajaran
Heuristik Vee dikumpulkan pada setelah berakhirnya pertemuan pada tes siklus III yaitu pertemuan ke-5 dari siklus III ,dengan menggunakan angket anggapan siswa yang terdiri dari 15 butir pernyataan yang disajikan pada lampiran 16. Data skor tanggapan siswa terhadap penerapan model pembelajaran Heuristik Vee dalam pembelajaran matematika secara lebih rinci dapat dilihat pada Lampiran 17. Ratarata skor tanggapan siswa terhadap penerapan model pembelajaran Heuristik Vee selama proses pembelajaran adalah sebagai berikut.

$\bar{X}=\frac{\sum_{i \rightarrow 1}^{40} x_{i}}{n}=\frac{2517}{40}=62,93$

Berdasarkan rata-rata tersebut, tanggapan siswa terhadap penerapan model pembelajaran Heuristik Vee ditinjau dari rata-ratanya berada pada kategori positif. Persentase tanggapan siswa terhadap penerapan model pembelajaran Heuristik Vee untuk masing-masing katagori dapat diperhatikan pada tabel berikut.

Tabel. 4 Persentase Tanggapan Siswa Terhadap Penerapan Model Pembelajaran Heuristik Vee untuk Masing-masing Katagori.

\begin{tabular}{|l|l|l|l|l|l|}
\cline { 2 - 6 } \multicolumn{1}{c|}{} & $\begin{array}{l}\text { San } \\
\text { gat } \\
\text { Neg } \\
\text { atif }\end{array}$ & $\begin{array}{l}\text { Neg } \\
\text { atif }\end{array}$ & $\begin{array}{l}\text { Cuk } \\
\text { up }\end{array}$ & $\begin{array}{l}\text { Pos } \\
\text { itif }\end{array}$ & $\begin{array}{l}\text { San } \\
\text { gat } \\
\text { Posi } \\
\text { tif }\end{array}$ \\
\hline $\begin{array}{l}\text { Banya } \\
\text { k } \\
\text { Siswa }\end{array}$ & - & - & - & 22 & 18 \\
\hline $\begin{array}{l}\text { Persen } \\
\text { tase }\end{array}$ & - & - & - & $55 \%$ & $45 \%$ \\
\hline
\end{tabular}

Sebaran data tanggapan siswa terhadap penerapan model pembelajaran Heuristik Vee dilihat pada Gambar 5. 


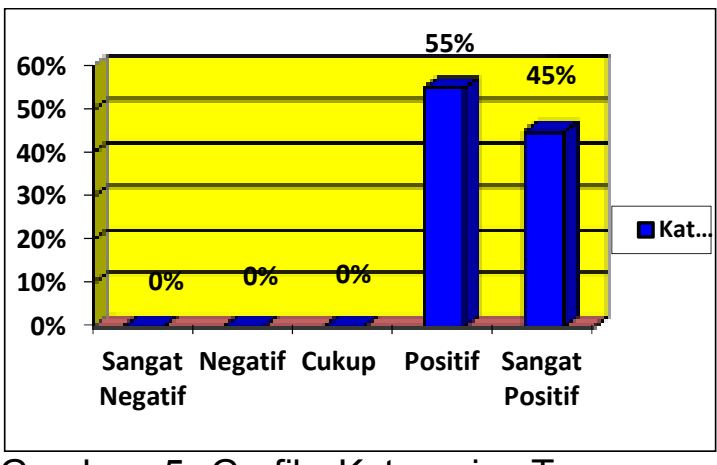

Gambar 5 Grafik Katagori Tanggapan Siswa Terhadap Penerapan Model Pembelajaran Heuristik Vee

Berdasarkan diagram 5 persentase kenatusiasan siswa dalam mengikuti pembelajaran dengan model pembelajaran Heuristik Vee ini sangat memberikan tanggapan yang positif dengan melihat grafik bahwa tanggapan positif siswa secara klasikal yaitu $55 \%$ dan sangat positif $45 \%$. Terlihat siswa senang dengan proses pembelajaran yang dilakukan dan bisa mengikuti dengan baik dari siklus I sampai siklus III dan memiliki dampak positif melalui model yang diterapkan dalam proses pembelajaran yang telah berlangsung.

\section{Pembahasan}

Berdasarkan hasil penelitian yang telah dilaksanakan selama tiga siklus menunjukkan terjadi peningkatan kemampuan pemahaman konsep matematika siswa kelas XI AP4 SMK Negeri 2 Singaraja melalui penerapan model pembelajaran Heuristik Vee. Hal ini sejalan dengan hasil penelitian yang dilakukan oleh A.harso, I.W. Suastra, A.A.I.A.R. Sudiatmika (2014). yang menyatakan bahwa hasil belajar kognitif siswa yang dibelajarkan dengan model pembelajaran Heuristik Vee telah mencapai proporsi ketuntasan klasikal selain itu hasil belajar afektif dan psikomotorik siswa yang dibelajarkan dengan model pembelajaran Heuristik Vee memiliki rata-rata yang lebih tinggi dibandingkan siswa yang dibelajarkan dengan model konvensional. Kesesuaian dengan hasil penelitian Ni Wayan Astiti, I Nengah Suadnyana, Ida Bagus Surya
Manuaba (2014) yaitu proses pelaksanaan model pembelajaran Heuristik Vee pada penelitian ini telah sesuai dengan teori dan kendala-kendala yang terjadi selama pelaksanaan penelitian sudah dapat ditangani melalui refleksi setiap siklusnya.

Pada pelaksanaan siklus I siswa mengalami kebingungan dalam melakukan eksplorasi menggunakan diagram Vee, karena sebelumnya siswa belum pernah menggunakan diagram Vee dalam pembelajaran. Pada kegiatan inti pembelajaran yaitu pada tahap eksplorasi siswa terlalu lama memberikan jawaban pada digram Vee sehingga waktu yang diperlukan untuk mengisi data hasil eksplorasi pada LKS cukup banyak. Pada saat menyimpulkan apa yang diperoleh dari hasil eksplorasinya sebagian besar siswa kebingungan dalam menuliskan kesimpulan hasil dari eksplorasi yang sudah dilakukan. Selain itu sebagian besar siswa masih enggan bertanya terkait halhal yang belum dimengerti. Berdasarkan kendala-kendala yang dihadapi pada siklus II guru melakukan refleksi untuk memperbaiki kendala-kendala dalam pembelajaran. Guru memberikan penekanan terkait petunjuk atau langkah kerja yang harus dilakukan oleh siswa dalam melakukan eksplorasi dengan pengisian jawaban pada diagram Vee, Selain itu guru juga memberikan bimbingan kepada masing-masing kelompok dalam pengerjaan LKS dan lebih memberikan arahan dalam pengisisan jawaban di diagram Vee agar alokasi waktu yang digunakan menjadi efektif. Guru memberikan penguatan dan memotivasi siwa agar berani bertanya terkait hal yang belum dipahami.

Pada pelaksanaan siklus II, proses pembelajaran berjalan lebih optimal. Siswa kelas XI AP4 SMK Negeri 2 Singaraja sudah mampu mengeksplorasi konsep dengan bantuan diagram Vee. Beberapa kelompok sudah mampu membuat kesimpulan terkait materi yang sedang dipelajari, namun ada beberapa kelompok yang masih membutuhkan bimbingan guru dalam membuat kesimpulan. Pada saat pembelajaran berlangsung, masih ada 
beberapa siswa yang kurang aktif. Mereka hanya mengandalkan anggota kelompok yang dirasa lebih pintar dari dirinya dalam mengerjakan permasalahan yang ada pada LKS. Dalam mempresentasikan hasil diskusi, beberapa kelompok terlihat hanya mengandalkan orang sama, anggota kelompok yang lain merasa takut salah dalam menyampaikan hasil diskusi kelompoknya. Pada saat mengerjakan soal cerita yang berkaitan dengan materi yang sedang dipelajari siswa mengalami kebingungan terkait maksud dari soal tersebut. Berdasarkan kendala-kendala yang dihadapi pada siklus II guru melakukan refleksi untuk memperbaiki kendala-kendala dalam pembelajaran. Dalam membuat kesimpulan guru kembali menekankan kepada siswa untuk mencermati data yang diperoleh dari hasil eksplorasi dan mengaitkannya dengan pertanyaan yang ada pada LKS. Guru memberikan motivasi kepada siswa untuk belajar dan menumbuhkan rasa tanggung jawab untuk bekerja sama dalam kelompok dalam mengerjakan permasalahan yang ada pada LKS.

Pada kegiatan presentasi, guru menunjuk salah satu perwakilan kelompok secara acak agar semua siswa dari masing-masing kelompok memiliki tanggung jawab dan termotivasi untuk melaksanakan diskusi kelompok dengan serius. Untuk lebih meningkatkan pemahaman siswa terkait soal cerita, soalsoal yang di buat berkaitan dengan kehidupan sehari-hari dan siswa diminta untuk melatihkan diri dirumah dalam mengerjakan soal terkait materi tersebut.. Dalam pelaksanaan siklus III, siswa berpartisipasi lebih aktif dalam pembelajaran, proses pembelajaran dengan model pembelajaran Heuristik Vee telah berlangsung dengan baik dan efektif selama pembelajaran baik dari segi waktu maupun prosesnya. Tindakan yang telah dilakukan oleh guru menjadikan siswa lebih aktif dan antusias dalam pembelajaran. Pada tahap eksplorasi siswa sudah mampu melakukan esplorasi dengan mengerjakan LKS dan menuangkannya dalam diagram
Vee dan menemukan konsep yang dipelajari.

Pada tahap mengaplikasikan konsep siswa sudah bisa memahami dan mengerjakan soal cerita yang berkaitan dengan materi yang dipelajari, menandakan siswa sudah memahami konsep dan bisa mengaplikasinya. Peningkatan pemahaman konsep matematika siswa terjadi secara optimal disebabkan karena pelaksanaan tindakan pada setiap siklusnya dengan menerapkan model pembelajaran Heuristik Vee selama pembelajaran dengan menekankan beberapa hal yaitu sebagai berikut. Pertama, guru memperjelas petunjuk atau langkah kerja pada saat pengisiaan diagram Vee sehingga siswa lebih mudah memahami apa yang harus dilakukan dengan diagram Vee tersebut. Hal ini berdampak pada alokasi waktu yang digunakan pada tahap eksplorasi menjadi lebih efektif. Sehingga proses pembelajaran yang terlaksana berlangsung sesuai dengan rencana pelaksanaan pembelajaran yang telah dirancang

Kedua, pada tahap penemuan konsep siswa diberikan penekanan terkait materi yang sedang dipelajari, dan mengaitkannya dengan pertanyaan yang ada, sehingga siswa mampu membuat kesimpulan dari materi yang dipelajari dengan kata-kata sendiri. Dapat memahami dan membuat kesimpulan dengan kata-kata sendiri berdampak pada meningkatnya kemampuan pemahaman konsep matematika siswa. Ketiga, pada saat presentasi kelompok, semua siswa dibiasakan untuk siap mempresentasikan hasil diskusi kelompoknya, tidak ada lagi kelompok yang hanya mengandalkan satu orang saja untuk mewakili kelompoknya. Hal ini berakibat pada setiap siswa melaksanakan diskusi dengan kelompoknya secara sungguh-sungguh agar mampu mewakili kelompoknya saat presentasi. Hasil penelitian ini sejalan dengan penelitian Ngadiyono (2014) yang menyatakkan bahwa kemampuan berfikir kreatif siswa yang menggunakan diagram vee lebih baik (signifikan) dari siswa yang 
menggunakan model pembelajaran langsung.

Berdasarkan hasil yang diperoleh, penelitian ini secara umum telah mampu menjawab rumusan masalah sekaligus telah mapu memecahkan permasalahan rendahnya pemahaman konsep matematika siswa. Penerapan model pembelajaran Heuristik Vee ini dapat meningkatkan pemahman konsep matematika siswa kelas XI AP4 SMK Negeri 2 Singaraja. Hal ini juga didukung oleh tanggapan positif siswa terhadap pembelajaran yang dilaksanakan. Dengan kata lain penelitian tindakan kelas berhasil dilaksanakan.

\section{SIMPULAN DAN SARAN}

Berdasarkan hasil penelitian dan pembahasan yang telah dipaparkan pada bab sebelumnya, dapat disimpulkan beberapa hal sebagai berikut. (1) Penerapan model pembelajaran Heuristi Vee dapat meningkatkan kemampuan pemahaman konsep matematika siswa kelas XI AP4 SMK Negeri 2 Singaraja tahun 2017/2018. Hal ini dapat dilihat dari ketuntasan belajar siswa yang meningkat dari siklus ke siklus dan mencapai indikatpr keberhasilan yang ditetapkan. Ketuntasan belajar siswa pada siklus I, siklus II dan siklus III berturut-turut yaitu $25 \%, 55 \%$ dan $85 \%$. Peningkatan tersebut terjadi selama pelaksanaan pembelajaran pada setiap siklus. Pada siklus I siswa masih bingung dan belum terbiasa dengan proses pembelajaran yang dilakukan, tetapi beberapa siswa sudah mampu mengikuti pembelajaran dengan model baru yang diterapkan. Diskusi kelompok terlihat masih banyak didominasi hanya satu orang saja, sedangkan anggota kelompok yang lain kurang berkontribusi dalam mengerjakan permasalahan pada LKS yang diberikan. Pada siklus II siswa sudah mulai terbiasa melakuka proses pemberlajaran dengan model baru yang diterapkan.tetapi dalam menyimpulkan suatu konsep dari hasil pembelajaran masih memerlukan bimbingan dari guru. Setiap siswa terlihat antusias dalam melakukan diskusi dengan kelompoknya meskipun beberapa siswa masih ada yang mengobrol dengan anggota kelompok yang lainnya. Pada siklus III siswa sudah terbiasa dengan pembelajaran yang dilakukan sudah mampu menemuka dan menyimpulkan konsep tanpa bimbingan dari guru. Selain itu, semua siswa juga terlihat aktif dalam diskusi dengan kelompoknya. Sehingga ini sangat berdampak positif pada peningkatan kemampuan pemahaman konsep matematika siswa. (2) Tanggapan siswa kelas XI AP4 SMK Negeri 2 Singaraja terhadap penerapan model pembelajaran Heuristik Vee ditinjau dari rata-ratanya berada pada katagori positif dengan rata-rata skor tanggapan siswa 43,3.

Berdasarkan temuan-temuan yang diperoleh dalam penelitian ini dapat diajukan beberapa saran sebagai berikut. (1) Bagi guru yang mengalami masalah rendahnya kemampuan pemahaman konsep matematika siswa, penerapan model pembelajaran Heuristik Vee dapat digunakan sebagai salah satu alternatif dalam menyelesaikan masalah tersebut. Untuk itu, kepada guru matematika pada umumnya, disarankan untuk mencoba menerapkan model pembelajaran Heuristik Vee pada pokok bahasan yang lain. (2) Diharapkan kepada pembaca yang berminat untuk melakukan penelitian lebih lanjut mengenai penerapan model pembelajaran Heuristik Vee agar memperhatikan kendala-kendala yang peneliti alami sebagai bahan pertimbangan untuk perbaikan dan penyempurnaan pelaksanaan penelitian.

\section{DAFTAR PUSTAKA}

Astiti, N W., dkk. 2014. "Penerapan Model Pembelajaran Heuristik Vee untuk Meningkatkan Hasil Belajar Ipa Siswa Kelas V Sekolah Dasar Negeri 14 Dauh Puri Denpasar Tahun Ajaran 2013/2014". Singaraja: Universitas Pendidikan Ganesha

Harso, Suastra dkk. 2014. Pengaruh Model Pembelajaran Heuristik Vee Terhadap Pemahaman Konsep Fisika Dan Sikap IImiah Siswa Kelas $X$ Sma Negeri 2 Langke Rembong 
Tahun Pelajaran 2013/201. eJournal Program Pascasarjana Universitas Pendidikan Ganesha Program Studi IPA (Volume 4 Tahun 2014)

NCTM, 2000. Principles And Standards For School Mathematics. Tersedia pada http://www.netm.org/uploadedFile/St andards and Positions/PSSM Exee ultiveSummary.pdf. Diakses pada tanggal 3 juli 2017

Putra, I.W.S.2015. Pengaruh Penerapan Strategi Quick On The Draw Terhadap Pemahaman Konsep Matematika Siswa Kelas XI MIPA SMAN 1 Amlapura. Jurnal Pendidikan Matematika Undiksha. Vol. 3. No. 1. Tahun 2015

Suarjana, I. M. 2014. Pengaruh Model Pembelajaran Heuristik-V Berbantuan Peta Konsep Terhadap Pemahaman Konsep IPA Siswakelas $V$. Jurnal PGSD Undiksha. Vol. 2. No. 1 Tahun 2014

Sucipta, Suastra dkk. 2014. Pengaruh Model PembelajaranHeuristik Vee Terhadap Pemahaman Konsep Fisika dan Sikap IImiah Siswa SM. e-Journal Program Pascasarjana Universitas Pendidikan Ganesha Program Studi IPA (Volume 4 Tahun 2014)

Wandari, P. P. S. 2015. Penerapan Strategi Pembelajaran College Bowl untuk Meningkatkan Aktivitas dan Pemahaman Konsep Matematika Siswa. Jurnal Pendidikan Matematika Undiksha, Vol. 3. No. 1. Tahun 2015. 